\title{
The Poetics of Blank Spaces and Intervals in Selected Works of Elisabeth Rynell
}

\author{
Antje Wischmann
}

The poetry collection I mina hus (2006, "In My Houses") appeared after the successful novel Hohaj (1997, Schneelandschaft 2002), ${ }^{1}$ which made the Swedish author Elisabeth Rynell known to a wide readership. It is not hard to discern motifs common to both her poetry and prose, such as descriptions of landscapes that speak to a number of sensory perceptions, seasonal cycles and intensive snapshot images. In the poems of I mina hus a suggestive technique of gaps for the reader's imagination is applied in the blank spaces: there are white spaces in the midst of the "poetic body" that create enjambments and ensure a striking overall layout. The blank space is a characteristic example of "textual form as sign" (Sabel and Glauser 2004, 6) and a counterpart to the inscription: "Hundar/ser exakt/det vi själva inte ser [ $]^{2}$ Min hund/hade en blick/rätt ur den gamla världen [ ]" ("Dogs/see precisely/what we can't see [ ] My $\mathrm{dog} /$ had a gaze/reaching out of the old world [ ]") (Rynell 2006, 8). ${ }^{3}$ This lacuna is referring to what is not be seen by humans; it establishes an analogy between the non-visual and the non-representational. But the

\footnotetext{
A. Wischmann $(\bowtie)$

Department of Scandinavian Literature and Culture, Universität Wien, Wien, Austria

(C) The Author(s) 2020

K. Malmio, K. Kurikka (eds.), Contemporary Nordic Literature and Spatiality, Geocriticism and Spatial Literary Studies, https://doi.org/10.1007/978-3-030-23353-2_8
} 
blank space can also be an interval or a pause and has sometimes an iconic function: "Jag kan känna/hugget in [ ]/i livet [ ]," ("I can feel/the cut/ [ ] into life [ ]") (Rynell 2006, 27). The experience of a "cut" seems to be performed within the linear writing and reading process. At the same time the blank spaces relate to each other, build up their own framework, as a kind of silent para-code, beside the textual.

In Rynell' s prose, a fusion of prose and poetry, the author inserts blank spaces as well, in two different ways: as lacunae like [ ] and as a kind of imaginary space between the story lines, when the focalization shifts from person to person or from the first-person narrator to a character. The readers have to relate the story lines to each other in order to grasp their personal interpretation of the novel (Hohaj and Hitta hem, 2009; "Finding home"). Especially in Hitta hem, the story lines first appear to be independent of each other because the main character Hild is living in the 1960s and her historic counterpart Mala in the seventeenth century. But after the readers have learned about passage or portal figures entering different (text) worlds, they will probably guess that Mala is a character in a literary text, written by the young author Hild. The melodramatic novel Hohaj even combines three focalizations: the first-person narrator (living in the twentieth century) has lost her husband, and this tragedy is mirrored in a love story of two outsiders, the female servant captured by her violent father (Inna) and the roaming poor seasonal worker (Aron), probably a Romani traveler or a Jew. Has the first-person narrator herself composed the traumatic story of Inna and Aron as part of a metanarrative and metafictional project? Readers will no doubt take different views on this. Literary scholar Thomas Seiler, for example, works on the assumption that Inna and Aron are characters invented by the writing first-person narrator (Seiler 2004), helping her to overcome her life crisis. The novel's levels are intertwined, with connections and passages to each other, and the readers may move in and out of the three character's parallel worlds: "Det finns portar i verkligheten./Går man in genom en av de portarna/kommer man ut i en annan berättelse./Hur många portar det finns, vet ingen" (Rynell 2009, epigraph, corresponding to page 5) ("There are portals in reality./ If you go through one of these portals,/you emerge into a different narrative./How many of these portals there are, no one knows").

In a striking way these portals or passages are used both as narrative and as metaphorical concepts in Rynell's texts. Blank spaces and lacunae are "unprinted" space entities, but they can appear as signs with different meanings or may even be omissions, for example, remnants of deleted 
words or letters: without doubt, they are never "quiet," but always say something to the readers. During reception, blank spaces and lacunae enfold as "space[s] of reader response" (Heitmann 2012, 217), analogous to the "Leerstellen" by the reader response literary theorist Wolfgang Iser in 1972. He analyzed how "Leerstellen" in the reader's reception generate additional meanings, sometimes as an intended supplement or emphatic enrichment.

In Rynell's text a lacuna is the smallest possible format of a blank space within the sentences of a poem. On an intratextual level the blank space between the poems and the book chapters offers imaginative space in order to complete the text by means of the reader's reception. Having the protagonists of Rynell's Hohaj and Hitta hem in mind, the recipients have to decide how they will relate the threads to each other: Which narrator is the creator of Inna's or Mara's level? Answering this question depends on the interpretation of the novel as a whole. This narrative-structural example illustrates that my particular focus will be (a) on the positioning of material text/blank space/space of response as spatial entities and their relations to each other and (b) on the meaning which is generated by these relational processes.

What interests me, in other words, is the process of placing, that is, of "positioning with respect to space (Anordnungen zu Räumen)," in this case with respect to spatiotextual entities, even more than the "positioning of entities in space (Anordnung der Gebilde im Raum)" (Löw 2004, 46; italics original). Michel Foucault's term "relations among sites" (1984, 2, in French "relations d'emplacement") also deals with placing processes and the relations between placings. Relational space (in contrast to the common spatial concept of the container; Löw 2001, 2004) is always constituted by the interaction of space and time. First, I will examine the spatiotextual composition of the "opening" and the two "closing" poems of I mina hus, entering and then leaving the "textual houses" of Rynell's poems. In the second part I want to discuss the relationship between the correlations of blank spaces and intervals to Rynell's narrative profile as a modernist writer.

\section{The Text-as-Building Metaphor in I Mina Hus}

There is, of course, a long tradition of comprehending the text-as-building, as one can live in a world of words and a universe of texts. The materials of language can be compared with building elements, for example, words 
can be compared with stone bricks; lines with the rafters of the roof; the page's paper with real estate grounds; the title of a chapter with the room of a building, or a floor or section. In the depicted world the cellar of a house may represent the hidden unconsciousness or repressed feelings, the loft can signify utopian thought or bohemian lifestyle, and so on. It is easy and productive to compare an architectural object with "textus" (tissue, weave) as both are artifacts.

Gaston Bachelard's phenomenological notion of La poétique de l'espace (originally in 1957) could be truly inspiring, if it did not rely on the rather limited concept of spatial containers.

Often the beginning of a text may be conceptualized as an entrance, as an opening to the fictional world. In Rynell's text, by shifting focalization the ending of one narrative thread can open up for another and to the imagined space of the reader's response. A lacuna in a poem opens up this space of reception, but this is even more so with the concrete blank space of the layout and the temporal intervals of a poetic text because the language of poetry is much more "foregrounded" than that of prose.

The 30 poems in I mina hus spread across five chapters, constructing their own textual spatiality as houses of poems. Further, houses function as frameworks just as the houses of Rynell's poems operate as a medium for reader's perceptions, they form the material condition of their conception of the social world and their surroundings.

On the one hand, the poems are two-dimensional texts on twodimensional pages, while on the other they establish a (metaphorical and literal) text-as-building: a unique form of textual housing. The textualspatial shape of the poems is, therefore, as important as their description and representation of space. The textual form as such becomes a theme and an object of reflection. This kind of textual spatiality, involving type and script, is called Schriftraum in German (Doetsch 2015, 73-87), which always encompasses both layout and the bodily act of writing and/or physical printing. ${ }^{4}$

When it comes to the arrangement of Rynell's lyric texts-elements of textual spatiality such as templates and typography-what we need to investigate are context and the relations between stanzas, lines, phrases and words. With their mutual relations in mind, we need to analyze the concrete placings of text on the page. The focus, then, must be on the positioning of select compositional elements vis-à-vis textual spatiality, elements that construct intra- or intertextual connections before the readers' 
eyes. The house of a text can only establish a temporary ensemble, the result of placings and positionings within language and literary texts.

In Rynell's works, the house mostly operates as a form or framework that facilitates positioning and placing. Further, the house becomes a model for material language and for language as a medium. Rather than through division into chapters, I mina hus is structured by simple graphic sketches of tiny houses. These outline images are used as an alternative numbering system, much like Roman numerals: from 1 single house to 5 adjacent houses (Rynell 2006, 69), 15 sketches in all. But rather than standardized logotypes, these sketches show traces of "manual treatment," combining drawing and inscription: two short lines for windows, another for the centrally positioned door. The ambiguity of the title is striking: "In my houses" now inevitably also means "in my poems" or "in my writings," which are rendered as one-of-a-kind and temporary artifacts. The title and the layout entrench the analogy between house and text or building and literary work. Just as the rooms in a building are connected by corridors or passageways, so the blank spaces are interconnecting openings between the texts, having concrete and metaphorical significance: leaving a given house means entering another locational or spatial domain. The outside of one construction could be part of the inside of another spatial unit; these shared elements may at times be the actual page of a book, or may refer to other pages and books. Compared with material books or pages, texts have neither clear endings nor distinct borders.

Leaving a building might also mean entering a larger structure or understanding that the interior space is always subsumed by a surrounding space or opens into an exterior space. Leaving a textual building means entering something else, something different-perhaps another building or a (temporary) world outside the text. It is according to this opening and contextualizing principle that Rynell's writings build on earlier textual buildings, integrating them or amalgamating them into an expanding arrangement of texts.

A poem's context can lead us into the neighboring poetic text. The lines of a poem can open up both into the diegetic site (the depicted place), the layout of the page and the "Schriftraum" or to places experienced by readers. From a character's internal point of view we may not immediately be able to judge the dimensions of the space encompassing a house. Is the spatial unit of a house essentially defined by its territorial extension or "container" or is it perceived through relational space? What 
could actually be the outside of the inside, just a further sphere of another inside, nested in one another?

The first poem in I mina hus provides the volume with an epigraph, which introduces the themes of nostalgia, vanishing places and temporary constellations. The volume thus begins by indicating strategies of textual interlinkage and possible paths of interpretation.

\section{TRASTARNA HAR INTAGIT TRÄDTOPPARNA}

Ur den blöta [ ] nyväckta jorden

ännu kall av snösmältning

föds rabarberna långsamt

i ett baklänges upprullande

med fotspjärn nere i det svarta

Världens ansikte

är inte läsbart [ ] vi måsta berätta oss

fram [ ] Vittnandet

en andra

födelse

[ ] Blodet

hinnorna

[ ] [ ] den tunga närande efterbörden

faller

och ett träd längst inne

i det blå

som vi äter oss grymtande fram

genom. (Rynell 2006, 4)

THE THRUSHES HAVE OCCUPIED THE TREETOPS/out of the moist [ ] newly awoken earth/still cold from the melting snow/the rhubarb plants are slowly born/by unfurling themselves backwards/pushing themselves up from a foothold down in the blackness//the face of the world/is not readable [ ] we have to narrate ourselves/forwards as we go along [ ] Witnessing/another/birth//[ ] The blood/the shells [ ] the rich nourishing afterbirth/falls down/and a tree deep within/in the blue/ that we gruntingly eat our way/through

The dynamism of the new rhubarb shoots resembles an arabesque alive with energy. The linear moving forward of the text is both illustrated and realized in a performative forward movement. In the first stanza the lacuna is introduced as a temporal interval, slowly shifting from the neutral 
"moist" to the pathos of "newly awoken earth." The connotations of this pause are hesitation and thoughtfulness. Like the third omission after "go along" the first marks the positioning of a temporal unit, almost as if the lyrical I was searching for an adequate expression. The next blank space is iconic because of the analogy between the unreadable and the invisible. The last stanza is obviously beginning with two intervals, within an enjambment from the last word of the second stanza ("birth"), illustrating the process of creation step by step; here preparing for the primitivist identification with an organism of nature.

In the last poem, at the volume's "exit," we are returned to the summery beginning - and are perhaps meant to pass through a portal leading to a landscape of memory, which reveals an epiphany, though it immediately erases it, even overriding, silencing and fading out the text through a self-reflexive deixis ("här," "here"). The allegoric reading ends with the whiteness of the page.

\section{JUNI}

Och tvärs genom denna tunga grönska

ser jag ett ansikte

[ ] vittra

som om vinden

när den för ett ögonblick gick genom lövverket

suddat ut det

ögonen [ ] munnen [ ] de exakta läpparna [ ] allt omändrat

kringrört [ ] utplånat

Jag vet inte efteråt

om detta ansikte någonsin funnits [ ] Kanhända

var det bara en bild i lövverket

framstampat ur en inre bild [ ] ur

hjärnans lövverk [ ] hjärnans

bländverk

en önskan [ ] en längtan efter

ett ansikte

jag säger sedan till natten: träd

mig nära

och natten färdas i löven

ankrad vid en enda [ ] ytterligt tunn

fågelröst 
som ur intet sprider sina toner

genom det bleka

grönskimrande mörkret [ ] Att allting

är så tillfälligt [ ] så skört

så lätt att utsudda här. (Rynell 2006, 83-4)

JUNE/And through the midst of the dense greenery/I see a face/[ ] weather/as if the wind/when it moves for a moment through the foliage/ obliterates it//the eyes [ ] the mouth [ ] the precise lips [ ] everything altered//mixed up [ ] wiped out//Afterwards I don't know,/whether there was ever such a face [ ] Perhaps/it was just an image in the foliage/ generated from an inner image [ ] from/the cerebral foliage [ ] the brain's/illusion/a desire [ ] a longing for/a face//then I tell the night: come/close to me//and the night moves forward through the leaves/ anchored in a single [ ] particularly faint/birdcall/which broadcasts its notes out of the void/through the pale/green-shimmering darkness [ ] that everything/is so temporary [ ] so fragile/so easily erasable here

The momentary appearance of a face evokes the theme of an "imagination," one that can traverse the boundary between an internal idea and a phenomenological perception in both directions; it may be located both within and outside the perceiving subject. In this way images are projected onto the perceived environment, while one's own perception seems called into question as the possible result of wishful thinking. Characteristically, this poem hints metaphorically at two lines and thus - in accordance with a musical metaphor-two voices: the spatiotemporal forward movement of the night occurs in alignment with a bird's call. However (in contrast to the novels), this linear orientation cannot be related to a narrative and is thus only partially comparable to the novels' alternating narrative perspectives.

Not only do the distinct blank spaces in "June," as visualized omissions, accentuate the recipient's need for interpretation, they also draw attention to the technique itself, that is, its poetic and "foregrounding" function. The blank spaces resist fluent reading, so it is impossible to appropriate the poems according to the "line-as-breath" principle (Hansson 2011, 47). They slow down the reading process, not least because the multiple references engendered by the enjambments must be examined in succession. This results in a reading experience characterized by running forward and running backward, which unsettles the chronology of the perceptual process: initially a face might look out from behind the greenery, then the text jumps to a face that is "absent yet again," because the components of the face, flanked by four blank spaces, cannot be reconstructed in retrospect. 
The locational adverb "här" (here) guides one's attention not just to the scenography and the place of the subject, but also to the space on the page that remains blank beneath the summer-focused vanitas. The highlight of the summer marks a turning point; the certainty of the seasonal rhythm already reminds one of the summer's loss; the intensity of the epiphanic moment therefore corresponds with the notion of death, emptiness and silence. ${ }^{6}$ By opening the poetic textual building to its typographical environment, the blank space is also compared with the loss of textual signs or the outer world as a universe encompassing totally different codes. ${ }^{7}$ The blank spaces after "inner image" and "desire" again correspond with the figure of non-resemblance, referring to phenomena which can hardly be put into words.

At the epilogue "conclusion" of the collection, the poem "Över" ("Over") presents a text-specific variant of obliteration: the elliptical lines indicate that the movement that plays such a prominent role here is coming to a stop. Stasis is setting in. As if along a nerve pathway, the textual buildings leads the reader's gaze across the poem's spatiotextual boundary into the extratextual world. In other words, the layout visualizes the text's capacity (through a linguistic code and an iconic symbol for linearity) to point beyond itself as a poem.

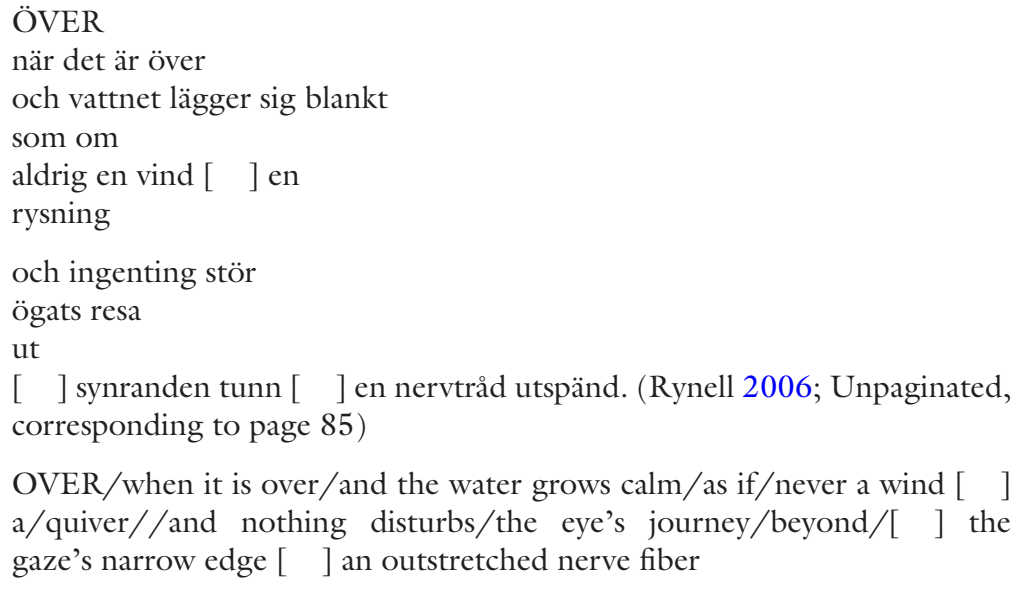

OVER/when it is over/and the water grows calm/as if/never a wind [ ] a/quiver//and nothing disturbs/the eye's journey/beyond/[ ] the gaze's narrow edge [ ] an outstretched nerve fiber

The last words - as an illusionary thread-make an attempt to leave the textual space, as if the "outstretched nerve fiber" was extending into the extraliterary world. This self-reflective and metapoetic method suggests a belief in "formal mimesis," by translating a physical phenomenon into a 
typographical counterpart: the line as a nerve. If one tried to visualize this transgressive movement, out of the embodied text, it would be a line, crossing the paper margin of the page ("edge"). This approach reminds one of the open endings in novels, because the characters of the embedded narrations establish the horizons for the characters of the frame narration (about the nameless female writer in Hohaj and Hild in Hitta hem). The concrete outside of a text may nevertheless correspond with the inner diegesis, and perhaps the extraliterary world is sometimes the most fictional world.

\section{Scrutinizing Modernist Foundations in the Fusion of Poetry and Prose}

The metaphor of a thread is part of the basic modernist repertoire in that it highlights constructedness as such (e.g., textus as tissue or weave). As the thread of life or fate and as a narrative guideline, it is also deployed in the third stanza of the well-known poem "Coda" (1938) by the famous modernist Swedish poet Gunnar Ekelöf (1907-1968), though in addition here emphasis is placed on a linear, irreversible orientation as a feature common to text and life: "Vad vore händelsernas vävnad utan/den röda tråden, ariadnetråden,/försvunnen då och då men alltid invävt!" "What would the weave of events be without/the red thread, the thread of Ariadne,/vanished now and then, but always woven in!" Translated by Larsson and Nathan 1982). This maxim emphasizing the importance of a strong narrative is the epigraph to Rynell's essay collection Skrivandets sinne (2013; "The Sense and the Senses of Writing"). In this work the author coins the term "human narrative" ("människo-berättelse"), which, in a metaphorical sense, relentlessly highlights the directed, dynamic and compressed character typical of the components of the "textus": "ett myller av trådar som löper framåt och bakåt, uppåt och nedåt som i en väv” (Rynell 2002, 100) ("a tangle of threads running forwards and backwards, upwards and downwards as in a weave"). Here we can discern a central line, a narrative thread, namely the "human narrative thread" (Rynell 2013, 39). Yet in neither the poetic nor the novel texts should we think in terms of a "naive thread" (solely in the sense of a focus that one ought to maintain): the blank spaces, intervals and threads always signalize that the texts (and the author) are aware of their self-referentiality from their "beginning." Readers are automatically confronted with this poetic method, intuitively taking part in the performance of material language and, in both her poetry and prose, confirming the perception of language as a medium. 
Nonetheless, in an essay on her argument about coherent or shattered narratives with Sara Lidman (1923-2004), who advocated the shattering of narratives (in the 1980s and 1990s, Wischmann 2014, 52-9), Rynell presents herself as a less experimental author, upholding a view of literature as a vigorous organism. Lidman is one of the most renowned classical modernists, known for her critical left-wing documentary prose (e.g., Gruva, "The Mine," 1968). In Lidman's late novels (e.g., Oskuldens minut, "Minute of Innocence," 1999) the characteristics of her work have gradually become grotesque and distorted, whereas Rynell still takes the principle of the organism more seriously. This prompts her to describe her narrative as a "viljekropp med obändig muskulatur," which possesses "en egen levande och tvingande kraft" (Rynell 2013, 37) ("a will-based body with an untameable musculature"; "an autonomous, living and compelling power"). Rynell favors clearly identifiable narratives, suggesting that she is a fairly traditional writer, at least in some ways. Her recurring critique of civilization entails a number of anachronistic features or throwbacks to early modernism: because she ascribes language to a primeval sphere and to a state of pre-consciousness, many of her texts tie the use of language directly to concepts of femininity, corporeality and ethnicity. ${ }^{8} \mathrm{By}$ referring explicitly to the Finland-Swedish and Swedish early modernist poets Edith Södergran (1892-1923) and Harry Martinson (1904-1978) in Skrivandet sinne, she encourages criticism of postmodern (or postpostmodern) life and artistic conditions, expressing a quite skeptical attitude to technology, consumerism and rationality. Here the similarities to Lidman's or Harry Martinson's literary and political engagement are plainly evident.

Rynell is undoubtedly a representative of eco- and feminist criticism, and her "modernist project" has to be understood in terms of a "renovation" or a late modern "retake" (Hassan and Hassan 1983; Eco 1985). Her work is deeply rooted in the literary debates on the nexus of the body and language of the 1980s and 1990s (Eglinger 2007). Transferring vitalism to a new era and integrating it with an awareness of inscriptions enables her poetry to "vitalize" textual spatiality and highlight the theme of embodied texts. The fact that the text, having entered the world, behaves in a creaturely way, looking at writers or readers and picking up a scent like an animal (Rynell 2013, 65), can only be explained if we assume that the anthropomorphization (on the premise of the texts' self-referentiality, see above) extends even to the self-reflexive unfolding of poems. In Rynell's poetry the graphic of the houses (as visual titles of the sections) claims that 
the poems could be conceived as if they were textual houses. In the novel Hitta hem a variety of story lines derives from the forest, as a tangle of springs and paths: “(...) det sprang upp berättelser ur den [skogen] som det springer upp källor ur marken. Berättelser som längs alla spår och stigar föddes och färdades, nästan som ett folk av berättelser som också de var en del av skogen" (Rynell 2009, 106) ("Narratives welled up from the forest like springs gushing from the ground. Narratives that were born of the trails and paths and traveled along them, almost like a people of narratives forming part of the forest"). The narrative and the poetic topology are more important than the depicted geographic places or topography.

In accordance with this nature-exoticizing concept of language, living bodies, natural elements and creatures even communicate on their own initiative, with no particular addressees: "Granar är retoriska figurer" or “en kväll så fullskriven av tecken” (Rynell 2006, 11, 9) ("Pines are rhetorical figures"; "an evening written full of symbols"). Characteristically, natural phenomena are always already symbolic entities, and they constitute a typographical landscape.

Rynell's compositional principle, as I have elaborated it here, is a variant in its own right when compared, for example, with Danish poet Inger Christensen's (1935-2009) novel Azorno (1967). In this ostentatiously fragmented novel, the depicted places and conflicts between characters are fused in several sequential permutations, creating a system of spatiotemporal units and establishing a unique set of rules, which recalls the Scandinavian (mostly Danish) poetry governed by script system principles ("systemdigtning”) of the 1960s and 1970s (Hejlskov Larsen 1971). In Christensen's novel, several narrating and writing figures alternately compete for the status of creator of that which has been narrated (Wischmann 1998). In a less complicated way this applies to Hohaj and Hitta hem as well. Which "thread" foregrounds the other? Which diegetic world is meant to be fictional/fictitious? These questions may be hard to answer. Even the textual building metaphor is applied by Christensen, for example, in a very famous poem ("Vandtrapper," "A Staircase of Water"), while material chapters are explicitly compared to the steps of a stone staircase (Christensen 1969, 45-6).

Yet in the framework of these works as a whole, as soon as we notice the genre-spanning attributes of Rynell's poetry and prose, we begin to pay due attention to their compositional intricacies. Rynell's late modernist novels emphatically revolve around a subject that writes, while concurrently being re-written by its texts. Both the textual buildings and the intertextual housings have an impact on both the production and the 
reception of Rynell's texts. The blank spaces and intervals have a spatiotemporal spell on the reader's reception: They are invited to spend some time to adapt poems and prose and to transform them into a highly personal reception experience.

\section{Notes}

1. There is no translation in English.

2. The [ ] symbol indicates a distinct blank space in the layout.

3. All translations in this chapter are by Antje Wischmann, in intense dialogue and negotiation with the translator Alex Skinner.

4. Doetsch calls the bodily gesture "Scription" (Doetsch 2015, 73-87).

5. Hansson understands the likes of William Carlos Williams and Allen Ginsberg as "line-as-breath" poets.

6. "Denn das Schöne ist nichts als das Schrecklichen Anfang, den wir gerade noch ertragen" (Rilke 1923, 11) ("For beauty is nothing but the beginning of terror that we are barely able to endure").

7. At the same time, the presentist "here" represents a verbal hinge to the title of the epilogue poem: "Över" ("Over"); as concluding vignette, this text is located outside the pagination. The poetics of empty spaces or signifiers referring to empty spaces is applied in a similar way by Ann Jäderlund in the early 1990s (see Brandt 2011, 2014).

8. Techniques of self-exoticization also appear in the poem "Poeten som smet" (Rynell 1988, 30).

\section{REFERENCES}

Bachelard, Gaston. 2014 [1957]. Poetik des Raumes. Translated by Kurt Leonhard. Frankfurt a.M.: Fischer.

Brandt, Tatjana. 2011. 'Kroppen med de dubbla pulsarna.' Karneval och tomrum i Ann Jäderlunds diktsamling Snart går jag $i$ sommaren ut. Tidskrift för litteraturvetenskap (1): 25-40.

- 2014. Livet mellan raderna. Revolt, tomrum och språkbrist i Ann Jäderlunds och Agneta Enckells tidiga poesi. Helsingfors: Helsingfors universitet. https://helda.helsinki.fi/bitstream/handle/10138/144089/livetmel. pdf?sequence $=1$.

Christensen, Inger. 1969. Vandtrapper. In Tekster fra slutningen af 60'erne, ed. Vagn Lundbye, 45-46. Copenhagen: Borgen.

Doetsch, Hermann. 2015. Schrifträume. In Handbuch Literatur und Raum, ed. Jörg Dünne and Andreas Mahler, vol. 3, 73-87. Berlin: De Gruyter. 
Eco, Umberto. 1985. Innovation and Repetition: Between Modern and Postmodern Aesthetics. Daedalus, Journal of the American Academy of Arts and Science 114 (4, fall): 161-184.

Eglinger, Hanna. 2007. Der Körper als Palimpsest. Die poetologische Dimension des Körpers. Freiburg: Rombach.

Foucault, Michel. 1984. Of Other Spaces: Utopias and Heterotopias. Translated by Jay Miskowiec, Architecture Mouvement Continuité(October): 1-9. http:// web.mit.edu/allanmc/www/foucaultl.pdf (print source Michel Foucault, and Jay Miskowiec, Diacritics, vol. 16, no. 1: 22-7).

Hansson, Gunnar D. 2011. Var slutar texten? Behöver man tala? In Var slutar texten? ed. Gunnar D. Hansson, 42-84. Gothenburg: Gothenburg University Press.

Hassan, Ihab, and Sally Hassan. 1983. Introduction. In Innovation/Renovation, ed. Ihab Hassan, 3-12. Madison, Wisconsin: The University of Wisconsin Press.

Heitmann, Annegret. 2012. Die Medialität des Aphorismus. In Am Rand. Zur Poetik des skandinavischen Aphorismus, ed. Katarina Yngborn et al., 213-244. Freiburg: Rombach.

Hejlskov Larsen, Steffen. 1971. Systemdigtningen. Modernismens tredje fase. Copenhagen: Munksgård.

Larsson, James, and Leonard Nathan (eds). 1982. Coda. Translated by James Larsson, and Leonard Nathan. In Songs of Something Else. Selected Poems of Gunnar Ekelöf, eds. James Larsson, and Leonard Nathan, 33. Princeton: Princeton University Press.

Löw, Martina. 2001. Raumsoziologie. Frankfurt a.M.: Suhrkamp. . 2004. Raum - Die topologischen Dimensionen der Kultur. In Handbuch der Kulturwissenschaften, ed. Friedrich Jaeger and Burkhard Liebsch, vol. 1, 46-59. Weimar: Metzler.

Rilke, Rainer Maria. 1974 [1923]. Duineser Elegien. Frankfurt a.M.: Suhrkamp. Rynell, Elisabeth. 1997. Hohaj. Stockholm: Bonniers.

- 1988. Sjuk fögel. Dikter. Stockholm: Bonnier.

- 2002. Schneelandschaft. Translated by Verena Reichel. Munich: Piper.

- 2006. I mina hus. Stockholm: Bonniers.

- 2009. Hitta hem. Stockholm: Bonniers.

- 2013. Skrivandets sinne. Essays. Stockholm: Bonniers.

Sabel, Barbara, and Jürg Glauser. 2004. Einleitung. In Text und Zeit. Wiederholung, Variante, Serie. Konstituenten literarischer Transmission, ed. Barbara Sabel and Jürg Glauser, 5-12. Würzburg: Königshausen und Neumann.

Seiler, Thomas. 2004. Figuren des Fremden in der skandinavischen Gegenwartsprosa: Herbjørnsrud, Hermanson, Rynell. Folia Scandinavica 8: 17-25. 
Wischmann, Antje. 1998. Inger Christensens Roman Azorno. In Ästhetik der skandinavischen Moderne, ed. Annegret Heitmann and Karin Hoff, 265-278. Frankfurt a.M.: Lang.

2014. Performing Space - A Modernist Hembygd. An Exploration of Sara Lidman's Works. Journal of Northern Studies, edited by Umeå University and the Royal Skyttean Society et al. 8 (1): 37-66.

Open Access This chapter is licensed under the terms of the Creative Commons Attribution 4.0 International License (http://creativecommons.org/licenses/ by $/ 4.0 /)$, which permits use, sharing, adaptation, distribution and reproduction in any medium or format, as long as you give appropriate credit to the original author(s) and the source, provide a link to the Creative Commons licence and indicate if changes were made.

The images or other third party material in this chapter are included in the chapter's Creative Commons licence, unless indicated otherwise in a credit line to the material. If material is not included in the chapter's Creative Commons licence and your intended use is not permitted by statutory regulation or exceeds the permitted use, you will need to obtain permission directly from the copyright holder.

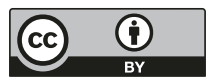

